\title{
Citrulline uptake in rat cerebral cortex slices: Modulation by Thioacetamide -Induced hepatic failure
}

\author{
Magdalena Zielińska • Marta Obara-Michlewska • \\ Wojciech Hilgier • Jan Albrecht
}

Received: 5 November 2013 / Accepted: 13 December 2013 / Published online: 3 January 2014

(C) The Author(s) 2014. This article is published with open access at Springerlink.com

\begin{abstract}
L-citrulline (Cit) is a co-product of NO synthesis and a direct L-arginine (Arg) precursor for de novo NO synthesis. Acute liver failure (ALF) is associated with increased nitric oxide (NO) and cyclic GMP (cGMP) synthesis in the brain, indirectly implicating a role for active transport of Cit. In the present study we characterized $\left[{ }^{3} \mathrm{H}\right] \mathrm{Cit}$ uptake to the cortical brain slices obtained from control rats and rats with thioacetamide (TAA)-induced ALF ("TAA slices"). In both control and TAA slices the uptake was partially $\mathrm{Na}^{+}$-dependent and markedly inhibited by substrates of systems $\mathrm{L}$ and $\mathrm{N}$, including L-glutamine (Gln), which accumulates in excess in brain during ALF. Cit uptake was not affected by Arg, the $\mathrm{y}^{+} /$ $\mathrm{y}^{+} \mathrm{L}$ transport system substrate, nor by amino acids taken up by systems $\mathrm{A}, \mathrm{x}_{\mathrm{c}}{ }^{-}$or $\mathrm{X}_{\mathrm{AG}}$. The $\mathrm{V}_{\max }$ of the uptake in TAA slices was $\sim 60 \%$ higher than in control slices. Chromatographic (HPLC) analysis revealed a $\sim 30 \%$ increase of Cit concentration in the cerebral cortical homogenates of TAA rats. The activity of argininosuccinate synthase (ASS) and argininosuccinate lyase (ASL), the two enzymes of CitNO cycle catalyzing synthesis of Arg, showed an increase in TAA rats, consistent with increased ASS and ASL protein expression, by $\sim 30$ and $\sim 20 \%$, respectively. The increased Cit-NO cycle activity was paralleled by increased expression of mRNA coding for inducible nitric oxide synthase (iNOS). Taken together, the results suggest a role for Cit in the activation of cerebral NO synthesis during ALF.
\end{abstract}

Keywords Acute liver failure · Thioacetamide Citrulline . Argininosuccinate syntethase $\cdot$ Argininosuccinate lyase . Nitric oxide

M. Zielińska $(\triangle) \cdot$ M. Obara-Michlewska $\cdot$ W. Hilgier $\cdot$

J. Albrecht $(\triangle)$

Department of Neurotoxicology, Medical Research Centre, Polish

Academy of Sciences, Pawinskiego 5, 02-106 Warsaw, Poland

e-mail: mzielinska@imdik.pan.pl

e-mail: jalb@imdik.pan.pl

\begin{abstract}
Abbreviations
ASS Arginosuccinate synthetase

ASL Arginosuccinate lyase

NOS Nitric oxide synthase
\end{abstract}

\section{Introduction}

Hepatic encephalopathy (HE), a consequence of acute or chronic liver failure (ALF or CLF), is a complex neuropsychiatric disorder that results from impaired clearance from blood of ammonia and other toxins, and is compounded by peripheral or local inflammatory processes (Prakash and Mullen 2010). The cellular and molecular mechanisms underlying HE are complex, but are as a rule associated with interference of ammonia with various aspects of brain metabolism, leading to imbalance of neural transmission (Albrecht and Jones 1999; Felipo and Butterworth 2002). At the molecular level the activation of ionotropic (mainly NMDA) glutamate receptors leads to increased intracellular free calcium which, after binding to calmodulin, activates nitric oxide synthase (NOS), leading to increased production of nitric oxide (NO) (Garthwaite et al. 1988). In ALF, ammoniainduced increase of $\mathrm{NO}$ and subsequently extracellular cGMP is a good indicator of the over-stimulation of NMDA receptors in rat brain, a process that contributes to increased reactive oxygen and nitrogen species (ROS/RNS) production (Kosenko et al. 2003; Hermenegildo et al. 2000; Hilgier et al. 2004). Increased NO synthesis under HE conditions in the brain, requires L-arginine (Arg) as a substrate for NOS, which generates NO and L-citrulline (Cit). Arg is a semi-essential amino acid in CNS and its availability depends both upon its uptake from the circulation (Fotiadis et al., 2013) and the recycling of Cit to Arg in Cit-NO cycle (Zhang et al. 1999, see also Scheme 1). Cit generated as a by-product of NO 


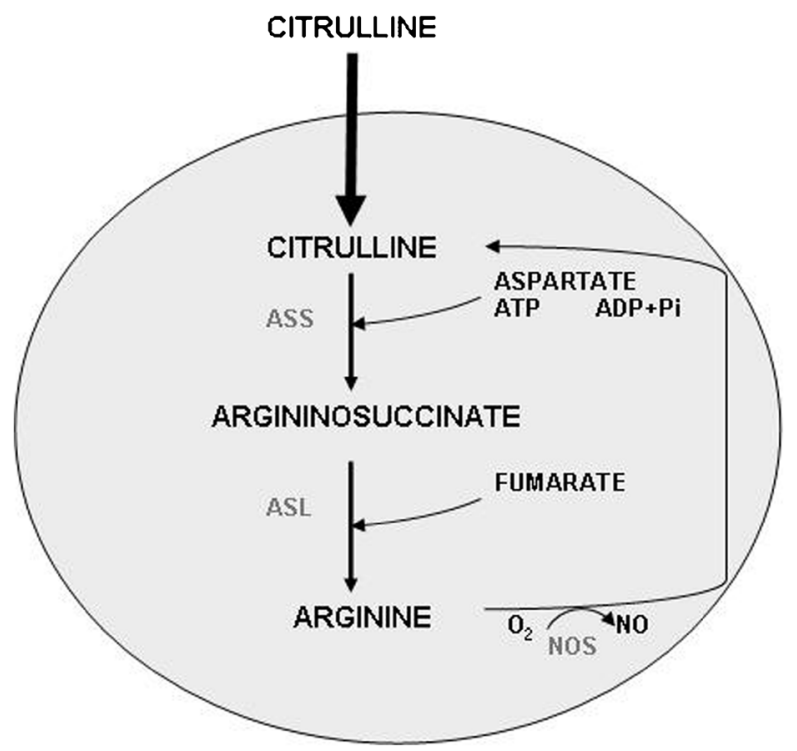

Scheme 1 The Cit-NO cycle in the brain. As suggested by this study, in TAA-induced ALF, increased amounts of Cit enter the brain cells, due to increased Cit uptake activity (as indicated by bold arrow). The increased Cit content in the brain tissue, stimulation of ASS and ASL, and increased iNOS expression, cooperatively enhance the Cit-NO cycle activity, positively modulating the NO tissue content

synthesis can be recycled to Arg in reactions subsequently catalyzed by argininosuccinate synthetase (ASS; EC 6.3.4.5) and argininosuccinate lyase (ASL; EC 4.3.2.1) via the Cit-NO cycle (Scheme 1). The activity of ASS and ASL was found increased in cerebral cortex of hyperammonemic rats (Swamy et al. 2005). Also, increased Arg uptake has been repeatedly demonstrated in ammonia-exposed synaptosomes (Westergaard et al. 1993; Rao and Butterworth 1996; Rao et al. 1997; Rao 2002) and astrocytes (Hazell and Norenberg 1998). Infusion of ammonium acetate to rats increased serum level of Arg, suggesting increased availability of Arg for NO synthesis (Ishihara et al. 1998). However, in TAA-induced ALF, the total blood to brain barrier transport of Arg was decreased, as determined by the brain uptake index (BUI) (Albrecht et al. 1996). Moreover, TAA-induced HE was associated with increased conversion of Arg to neurotransmitters Glu and $\gamma$-aminobutyric acid (GABA), a process engaging increased activities of arginase (AR; EC 3.5.3.1) and ornithine aminotransferase (OAT; EC 2.6.1.13) (Albrecht et al. 1990). On the other hand, elevated concentration of Lglutamine (Gln) in hyperammonemic rat brain inhibits cGMP synthesis by interaction with Arg transport into the cells (Zielinska et al. 2011), which could counter the increase of NO synthesis by ammonia. One other mechanism by which Gln could affect NO synthesis in the brain is by interference with Cit recycling to Arg, as shown by $\mathrm{Wu}$ and Meininger (1993) in peripheral endothelial cells. The potential importance of Cit recycling for Arg availability and NO synthesis in HE affected brain prompted us to analyze the as yet not considered Cit transport as a critical step within the Cit-NO cycle. The present study is, to the best of our knowledge, the first which attempted to characterize in more detail Cit transport in ex vivo brain tissue.

\section{Experimental procedures}

HE model

Adult male Sprague-Dawley rats (150-180 g) were reared under standard conditions at the local animal facility. The animals had free access to food and water. All experiments were performed with agreement of local animal ethical committee that approved the experimental design. HE with cerebral metabolic changes and symptoms typical of acute HE was induced by 3 i.p. injections of thioacetamide (TAA) $(250 \mathrm{mg}$ per kg of body weight) at $24 \mathrm{~h}$ hours intervals (Hilgier and Olson 1994; Hilgier et al. 1996) and sacrificed $24 \mathrm{~h}$ after third injection. Control rats were analogically injected with sodium saline solution.

\section{Cerebral cortical slices}

Male Sprague-Dowley rats (150-180 g) were used throughout. In essence, a previously described procedure was followed (Zielińska et al. 1999) with slight modifications. Animals were decapitated and the brains were immediately transferred into ice-cold Krebs-Ringer bicarbonate buffer (Krebs buffer) of the following composition: $118 \mathrm{mM} \mathrm{NaCl}, 25 \mathrm{mM}$ $\mathrm{NaHCO}_{3}, 4.7 \mathrm{mM} \mathrm{KCl}, 1.2 \mathrm{mM} \mathrm{KH} \mathrm{PO}_{4}, 2.5 \mathrm{mM} \mathrm{CaCl}$, $1.2 \mathrm{mM} \mathrm{MgSO}_{4}, 10 \mathrm{mM}$ glucose, aerated with $95 \% \mathrm{O}_{2}$ and $5 \% \mathrm{CO}_{2}$ at $\mathrm{pH}$ 7.4. After preparation the cortices were cut into $300 \mu \mathrm{m}$ slices using a manual chopper. The slices were transferred to borosilicate glass vials containing Krebs buffer. Each vial received its own supply of a $95 \% \mathrm{O}_{2}$ and $5 \% \mathrm{CO}_{2}$ gas mixture. The slices were pre-incubated under these conditions for $30 \mathrm{~min}$ in a water bath at $37.4{ }^{\circ} \mathrm{C}$.

Uptake experiments

After pre-incubation of cerebral cortical slices the uptake was started by adding $\left[{ }^{3} \mathrm{H}\right] \mathrm{Cit}$ at $100 \mu \mathrm{mol} / \mathrm{L}$ final concentration and the incubation was continued for $7 \mathrm{~min}$. Kinetics of $\left[{ }^{3} \mathrm{H}\right]$ Cit uptake was determined in $\mathrm{Na}^{+}$-containing medium over varying extracellular Cit concentrations $(2.5-1,000 \mu \mathrm{M})$. Substrate preference analysis was measured in a competition study where $100 \mu \mathrm{M} / \mathrm{L}\left[{ }^{3} \mathrm{H}\right] \mathrm{Cit}$ was used together with unlabelled $\mathrm{Cit}$ in the presence of a number of $0.5-10 \mathrm{mM}$ competing unlabelled L-amino acids or MeAIB (all substrates were from Sigma- Aldrich, USA).

The incubation was terminated by a rapid vacuum filtration through $2.5 \mathrm{~cm} 0.45 \mu \mathrm{m}$ Millipore filter disks (Millipore, 
Ireland), followed by three washes with $2 \mathrm{ml}$ with Krebs buffer maintained at $4{ }^{\circ} \mathrm{C}$. The radioactivity on filter disks was measured in a Wallac 1409 Liquid Scintillation Counter (Perkin - Elmer, Finland). Correction for the remaining citrulline in the extracellular space was included in blank samples, defined as zero-time incubation $(<20 \mathrm{~s})$ and accounted for about $7-10 \%$ of the total uptake. Protein determination was performed according to Bradford's procedure (Bradford 1976).

Argininosuccinate synthetase and argininosuccinate lyase activity measurements

Argininosuccinate synthetase (ASS) and arginosuccinate lyase (ASL) activity was measured by a modification of a method of Swamy et al. (2005). Briefly, the cortical tissue was weighed and homogenized in $0.05 \mathrm{M}$ phosphate buffer at $\mathrm{pH} 7.3$ and $4{ }^{\circ} \mathrm{C}$. The assay of ASS was started by the addition of $0.2 \mathrm{ml}$ of $20 \%$ homogenate to the reaction mixture contained Cit, aspartic acid, ATP, magnesium chloride, each at $0.01 \mathrm{M}$ concentration and $21 \mathrm{U}$ of arginase. The reaction was conducted at $37^{\circ} \mathrm{C}$ and stopped after $1 \mathrm{~h}$ by addition of $0.2 \mathrm{ml}$ of $50 \%$ trichloracetic acid. The reaction mixture was then centrifuged and supernatant was used for colorimetric determination of urea. The absorbance was read at $540 \mathrm{~nm}$. The reaction mixture for ASL assay contained argininosuccinate at $6.0 \mathrm{mM}$ and $10.5 \mathrm{U}$ of arginase and was started by addition of $0.2 \mathrm{ml}$ of $20 \%$ homogenate to the reaction mixture.

L-citrulline determination in cerebral cortical homogenates

Cit was analysed using HPLC with fluorescence detection after derivatisation in a timed reaction with o-phthalaldehyde plus mercaptoethanol, as described earlier (Zielińska et al. 1999). Derivatised samples (50 $\mu$ l of microdialysate) were injected onto $150 \times 4.6 \mathrm{~mm} 5 \mu \mathrm{m}$ Hypersil ODS column, eluted with a mobile phase of $0.075 \mathrm{M} \mathrm{KH}_{2} \mathrm{PO}_{4}$ solution containing $10 \%(\mathrm{v} / \mathrm{v})$ methanol, $\mathrm{pH} 6.2$ (solvent $\mathrm{A}$ ), and methanol (solvent B). The methanol gradient was $20-70 \%$ and the elution time $20 \mathrm{~min}$.

\section{Protein isolation and Western blot analysis}

Isolated rat brain cerebral cortexes were homogenized and centrifuged at $4^{\circ} \mathrm{C}$ with Triton Lysis Buffer as described earlier (Zielinska et al. 2011). Total protein concentration in supernatants was determined by the Lowry method using Modified Lowry Protein Assay Reagent (Pierce). Protein (30 $\mu \mathrm{g})$ was mixed with sample loading buffer, separated on SDS-PAGE and then transferred onto nitrocellulose membrane. The membranes were blocked with $5 \%$ non-fat dry milk in TBS-T buffer. Incubation with antibodies against ASS
(1:1,000, Sigma-Aldrich, USA) and ASL (1:1,000, SigmaAldrich, USA) was done in TBS-T buffer with $5 \%$ non-fat dry milk at $4{ }^{\circ} \mathrm{C}$ temperature over night followed by $10 \mathrm{~min}$ incubation with peroxidase-conjugated-anti-rabbit antibodies (1:2,500, Sigma-Aldrich, USA) for detection by SuperSignal West Pico Chemiluminescent Substrate (Pierce). The first antibody was stripped off with $0.1 \mathrm{M}$ glycine, $\mathrm{pH} 2.9$, and second incubation was performed with an antibody against GAPDH (1 $\mathrm{h}$ at room temperature), (1:5,000, Sigma-Aldrich, USA).

Real-time PCR analysis

Total RNA was isolated using TRI Reagent (Sigma-Aldrich, USA), and then $1 \mu \mathrm{g}$ was reverse-transcribed using the High Capacity cDNA Reverse Transcription Kit (Applied Biosystems, Life Technologies). Real time PCR was performed in 96 well plates with the ABI 7500 apparatus (Applied Biosystems, Life Technologies) using the MGB Taqman probe assay. Probes for iNOS and endogenous control $\beta$-actin were purchased from Applied Biosystems (Rn 00561646-m1 and Rn 00667869-m1, respectively). Each reaction contained $5 \mu \mathrm{l}$ Taqman Universal PCR Mastermix in a total volume of $10 \mu \mathrm{l}$, and $1 \mu \mathrm{l}$ cDNA was added to the reaction. The real time $\mathrm{PCR}$ reactions were performed at $95{ }^{\circ} \mathrm{C}$ for $10 \mathrm{~min}$, followed by 40 cycles of $30 \mathrm{~s}$ at $95{ }^{\circ} \mathrm{C}$ and $1 \mathrm{~min}$ at $60^{\circ} \mathrm{C}$. The results of the analysis were calculated in relation to the $\beta$-actin product, and results were calculated according to, and expressed by an equation $\left(2^{-\Delta \Delta C t}\right)$ that gives the amount of target, normalized to an endogenous reference and relative to a calibrator. $\mathrm{C}_{\mathrm{T}}$ is the threshold cycle for target amplification (Livak and Schmittgen 2001).

\section{Statistical analysis}

Statistical analysis of the data was performed using one-way analysis of variance followed by the Dunnet's comparison test or the two-tailed Student's test.

\section{Results}

Kinetics of $\left[{ }^{3} \mathrm{H}\right] \mathrm{Cit}$ uptake to the rat cerebral cortical slices was analyzed using Michaelis-Menten nonlinear analysis (Fig. 1a) and linearized transformation Eadie-Hofstee (Fig. 1b). The analyzes revealed a simple, one component of the uptake, where $\mathrm{V}_{\text {MAX }}$ of increased from $289 \pm 59$ to $471 \pm$

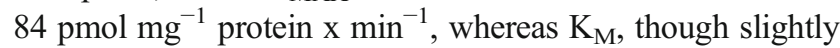
increased (from $11 \pm 4$ to $25 \pm 6 \mathrm{mM}$ ) in slices obtained from TAA-induces ALF rats (TAA) (Fig. 1a). Transport of $\left[{ }^{3} \mathrm{H}\right] \mathrm{Cit}$ was partially dependent on extracellular $\mathrm{Na}^{+}$, (Table 1) and significantly inhibited by a 10 -fold excess of unlabelled Cit, L-histidine (His; substrate for system L), L-glutamine (Gln; 

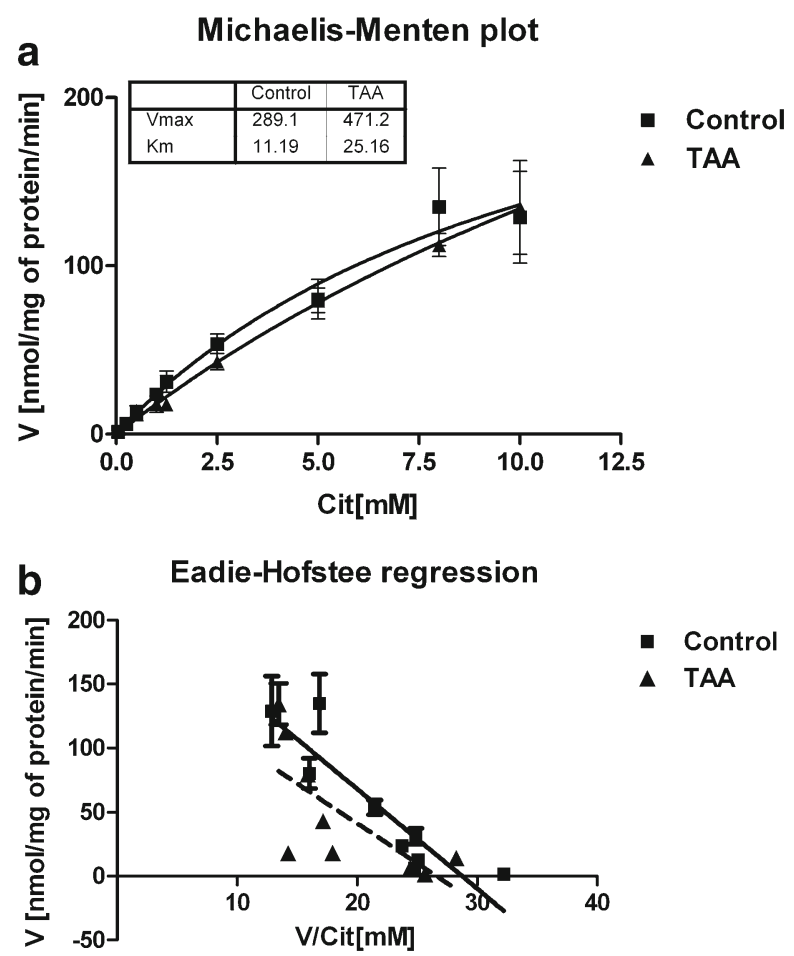

Fig. 1 a-b Kinetics of L-citrulline transport measured in cerebral cortical slices derived from control and TAA rats and analyzed in three different modes. Results are mean $\pm \operatorname{SD}(n=4-5)$

substrate for systems $\mathrm{L}$ and $\mathrm{N}$ ) or different concentrations of L-phenylalanine (Phe; substrate for system L) and 6-diazo-5-

Table 1 The effects of extracellular sodium and system-selective aminoacid substrates on L-citrulline uptake in cerebral cortical slices from control and TAA rats

\begin{tabular}{llcc}
\hline Inhibitor & System selectivity & \multicolumn{2}{c}{$\begin{array}{l}\text { L-citrulline transport } \\
(\% \text { control })\end{array}$} \\
\cline { 3 - 4 } & & Control & TAA \\
\hline $\mathrm{Na}^{+}$ & ${\mathrm{L}, \mathrm{N}, \mathrm{y}^{+}, \mathrm{x}_{\mathrm{c}},-\mathrm{X}_{\mathrm{AG}}}$ & $103 \pm 19$ & $153 \pm 18^{*}$ \\
$\mathrm{Na}^{+}$- free & $\mathrm{A}, \mathrm{N}$ & $72 \pm 20$ & $89 \pm 26^{* *}$ \\
L-arginine $(10 \mathrm{mM})$ & $\mathrm{y}^{+}$ & $71 \pm 29$ & $101 \pm 23$ \\
L-citrulline $(10 \mathrm{mM})$ & $?$ & $58 \pm 14^{*}$ & $82 \pm 26^{* *}$ \\
BCH (10 mM) & $\mathrm{L}$ & $48 \pm 14^{*}$ & $62 \pm 26^{* *}$ \\
L-glutamine $(10 \mathrm{mM})$ & $\mathrm{L}, \mathrm{N}$ & $60 \pm 14^{*}$ & $71 \pm 23^{* *}$ \\
L-histidine $(10 \mathrm{mM})$ & $\mathrm{N}$ & $46 \pm 15^{*}$ & $65 \pm 21^{* *}$ \\
DON (5 mM) & $\mathrm{N}$ & $47 \pm 16^{*}$ & $75 \pm 22^{* *}$ \\
MeAIB $(10 \mathrm{mM})$ & $\mathrm{A}$ & $98 \pm 14$ & $102 \pm 26$ \\
L-glutamate & $\mathrm{x}_{\mathrm{c}}-$ or $\mathrm{X}_{\mathrm{AG}}$ & $90 \pm 17$ & $116 \pm 20$ \\
\hline
\end{tabular}

Transport of L-citrulline $(0.1 \mathrm{mM})$ was measured over $7 \mathrm{~min}$ in the absence or presence of $\mathrm{Na}^{+}$ions and an excess of system-selective amino-acid substrates. Data are expressed as a percentage of the influx rate in control slices $(100 \%=19.2 \mathrm{pmol} \mathrm{mg}$ protein- $1 \mathrm{~min}-1)$. Values are mean $\pm \mathrm{SD}$ of 4-6 experiments with three replicates in each experiment. ${ }^{*} p<0.05$ vs. Control and ${ }^{* *} p<0.05$ vs. to TAA oxo-1-norleucine (DON; model substrate for system N). In contrast, 2-methylaminoisobutyric acid (MeAIB) and Lglutamate (Glu) (substrates for systems $\mathrm{A}$ and $\mathrm{xc}^{-} / \mathrm{X}_{\mathrm{AG}}$ ), respectively, were ineffective inhibitors, as well as Larginine (Arg), a substrate for $\mathrm{y}^{+}$system (Table 1). Detailed analysis of the inhibition of $\left[{ }^{3} \mathrm{H}\right] \mathrm{Cit}$ transport in control and TAA slices by DON revealed inhibition in a concentrationdependent manner, reducing $\left[{ }^{3} \mathrm{H}\right] \mathrm{Cit}$ uptake by $\sim 54, \sim 39$, $\sim 29 \%$ and $\sim 70, \sim 55$ and $\sim 50 \%$, respectively at $5 ; 2.5$; and $1 \mathrm{mM}$ concentration (Fig. 2a). In contrast, the inhibition caused by $3 \mathrm{mM}$ Phe was not further enhanced by increasing extracellular Phe to $15 \mathrm{mM}$ (Fig. 2b).

Chromatographic analysis of cerebral homogenates obtained from control and TAA rats revealed an increase in total tissue concentration of Cit from $1.3 \pm 0.2$ to $1.7 \pm 0.1 \mu \mathrm{M} / \mathrm{g}$ of tissue (Table 2). In TAA rats total tissue concentration of Arg increased from $10.6 \pm 0.6$ to $7.2 \pm 0.2$ (Table 2). The mRNA expression of iNOS was increased in TAA cortex by $\sim 20 \%$ of control, respectively (Fig. 3). TAA increased the activity of ASS (0.5-fold) and ASL (0.9-fold) in cerebral cortical homogenates (Fig. 4a). Western blot analysis showed increased expression of ASS ( $\sim 0.3$-fold) and ASL ( $\sim 0.2$-fold) in TAA rats (Fig. 4b).

\section{Discussion}

In the brain, astrocytes are the main site of ammonia detoxification, through the amidation of glutamate (Glu) forming Gln (Cooper and Plum 1987), in the reaction catalyzed by glutamine synthetase (GS) (Martinez-Hernandez et al. 1977). Accumulation of Gln in the brain in HE patients or animal models of ALF is one of the main factors that contribute to ammonia-induced neurotoxicity (Albrecht and Norenberg 2006). HE impairs the glutamate/NO/cGMP pathway, which includes interference with the synthesis of $\mathrm{NO}$ (Hermenegildo et al. 1998; 2000; Hilgier et al. 2004; for a review see Felipo 2006). Previously we showed that the impairment of the NOcGMP pathway may also result from the interference of Gln with Arg availability for NO synthesis. However, as was suggested by $\mathrm{Wu}$ and Meininger (1993) in the study on peripheral endothelial cells, Gln could also affect NO synthesis in the brain by interfering with recycling of the Arg precursor Cit. The capacity of the enzymes involved in Arg regeneration from Cit may represent a rate limiting mechanism in brain cells for maintaining substrate supply for NO synthesis. In relevance to the above consideration, activation of the Cit-NO biosynthetic pathway related to the markedly enhanced ASS, the rate-limiting enzyme in the pathway, was observed in alcoholic liver (Leung et al. 2012). In the present study, ALF caused a parallel increase of ASS activity and iNOS expression. To this point, the present study supports the few previous observations made in other experimental 

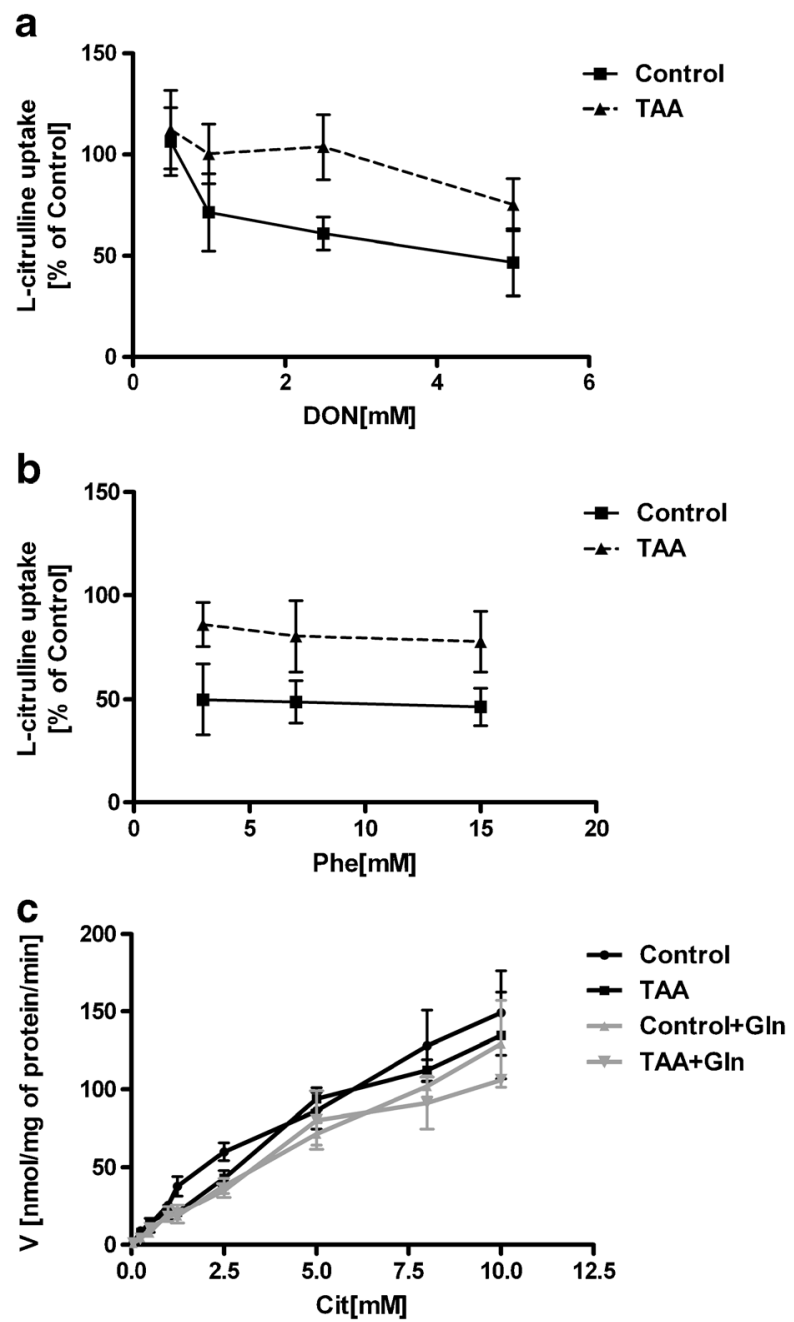

Fig. 2 Specificity of L-citrulline transport in cerebral cortical slices from control and TAA rat brain. Inhibition of L-citrulline transport was measured in slices incubated with $\mathrm{Na}^{+}$containing Krebs buffer with increasing concentrations $(0.5-5 \mathrm{mM})$ of DON (A) or L-phenylalanine (B). (C) Kinetic analysis of Cit uptake in the presence of $5 \mathrm{mM} \mathrm{Gln}$. Transport of L-citrulline $(0.1 \mathrm{mM})$ was measured over $7 \mathrm{~min}$, and expressed as a percentage of the transport rate determined in the absence of an inhibitor amino acid. Values are mean $\pm \operatorname{SD}(n=5-6)$

settings. Braissant et al. (1999) showed that expression of ASS and ASL genes is selectively induced in astrocytes treated

Table 2 Total concentration of L-citrulline and L-arginine in cortical slices from control and TAA rats

Amino acids concentration in rat brain cortex

( $\mu \mathrm{mol} / \mathrm{g}$ wet tissue)

Control TAA

\begin{tabular}{lll}
\hline L-citrulline & $1.3 \pm 0.2$ & $1.7 \pm 0.1^{*}$ \\
L-arginine & $10.6 \pm 0.6$ & $7.2 \pm 0.2^{* *}$ \\
\hline
\end{tabular}

Results are mean $\pm \mathrm{SD} ;(n=6) * p<0.05$ vs. "Control" with $5 \mathrm{mM} \mathrm{NH}_{4} \mathrm{Cl}$, also suggesting increased recycling of Cit to Arg. Moreover, the study Sharma et al. (2012) on devascularized porcine model of ALF provided indirect evidence for increased de novo synthesis of Arg via Cit-NO cycle.

One as yet unattended step in this cycle of potential rate-limiting impact was the uptake of the Arg precursor Cit. In this study therefore we characterized Cit uptake to the cerebrocortical slices obtained from control rats and rats with TAA-induced ALF, considering this as a potential additive factor in Arg supply for NO synthesis. The study by Albrecht et al. (1996) has analyzed a different stage of the TAA model: the animals were in the recovery period after the TAA insult ( 7 or 28 days). By contrast rats with TAA induced HE in the model here described (Albrecht et al. 1990) presented increased conversion of Arg to downstream metabolites. There is limited information on Cit transport in brain preparations or cells, and the properties of transporters involved in Cit uptake in peripheral tissues show considerable variations. For example, Cit uptake is predominantly $\mathrm{Na}^{+}$-dependent in rat small interstitium (Vadgama and Evered 1992), but is primarily $\mathrm{Na}^{+}$-independent and mediated by system L, and only partly by system $\mathrm{N}$ in rat aortic smooth muscle cells (Wileman et al. 2003). In turn, in pulmonary arterial endothelial cells, exposure to hypoxia evokes system Amediated Cit uptake (Fike et al. 2012). In rat kidney slices, Cit uptake was largely mediated by the $\mathrm{Na}^{+}$-independent organic anion transporter, OAT1 (Nakakariya et al. 2009). The characteristics of Cit uptake to brain slices showed many features in common with those described in aortic smooth muscle cells or rat small interstitium, largely matching transport systems $\mathrm{N}$ and $\mathrm{L}$.

Rat cerebral cortical $\left[^{3} \mathrm{H}\right]$ Cit uptake was increased by TAAinduced ALF rat cortex. The increase of $\mathrm{V}_{\max }$ of the uptake could be partially due to increased activity of the transporter and/or elevated total Cit concentration in the tissue (Table 2); the relative quantitative contribution of either of the two variables remains to be analyzed in more detail. Increased Cit uptake could be ascribed to two transporting systems: $\mathrm{N}$ and L. The involvement of the two systems is consistent with a previous report that Cit uptake in a variety of neural cell cultures is $\mathrm{Na}^{+}$-independent (Schmidlin et al. 2000). The involvement of the two systems indicates that in the setting of HE, the uptake would show increased sensitivity to, and thus a preponderance to be regulated by, a number of amino acids which are substrates of this system. Of note in this context, system L substrates Gln and Try show increased brain concentration in this model (Hilgier et al. 1992); their specific modulatory role in the Cit-NO cycle remains to be envisaged. While inhibition of Cit uptake by MeAIB and glutamate in TAA cortical slices could suggest the activation of other transport systems $\left(\mathrm{A}, \mathrm{x}_{\mathrm{c}}{ }^{-}\right.$or $\left.\mathrm{X}_{\mathrm{AG}}\right)$, decreased expression of 


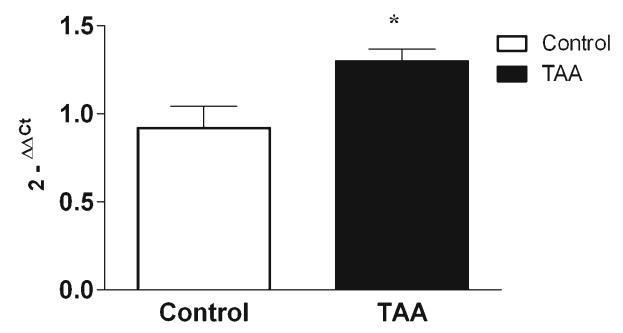

Fig. 3 The expression of iNOS mRNA in the cerebral cortex of control and TAA rats. Results are mean $\pm \mathrm{SD} ;(n=5) * p<0.05$ vs. "Control"

mRNA expression of two members of system A (SAT1, SAT2) (unpublished observations) tends to exclude this possibility. The involvement of systems: $\mathrm{A}, \mathrm{x}_{\mathrm{c}}{ }^{-}$and $\mathrm{X}_{\mathrm{AG}}$ in Cit transport deserves further investigation.

In conclusion, increased Cit uptake plus elevation of other parameters of the Cit-NO cycle unambiguously point to its stimulatory effect on NO synthesis in the setting of ALF, as illustrated in Scheme 1. To summarize briefly, Cit concentration in brain homogenates from TAA rat was elevated (Table 2), and so were the activities and expression of the two pertinent enzymes: ASS and ASL (Fig. 4a, b). One other factor with a potential to speed up the operation of the cycle is increased NOS activity. NO synthesis was repeatedly found elevated in different HE models (Schliess et al. 2002; Hilgier et al. 2004; 2009; Sharma et al. 2012), mostly due to increased iNOS, as shown in rats with chronic liver failure due to portacaval shunt (Rodrigo et al. 2007). In agreement with the previously reported data, here we document increased expression of iNOS mRNA in the TAA model of ALF. It remains to be confirmed whether the increase of mRNA is translated to increased iNOS protein level and NOS activity, as suggested by data from other groups (Rodrigo et al. 2007; Balasubramaniyan et al. 2012). Clearly, elucidation the role of NO synthesis in the present model will require an analysis of other NOS isoforms at the level of transcription, translation and enzyme activity. On the other hand, it must be kept in mind that Cit has only a limited ability to sustain maximal rates of NO
Fig. 4 The activity (a) and protein expression (b) of arginosuccinate synthetase (ASS) and arginosuccinate lyase (ASL) in the cerebral cortex of control and TAA rats. Results are mean \pm $\mathrm{SD} ;(n=4-5) * p<0.05$ vs. "Control"
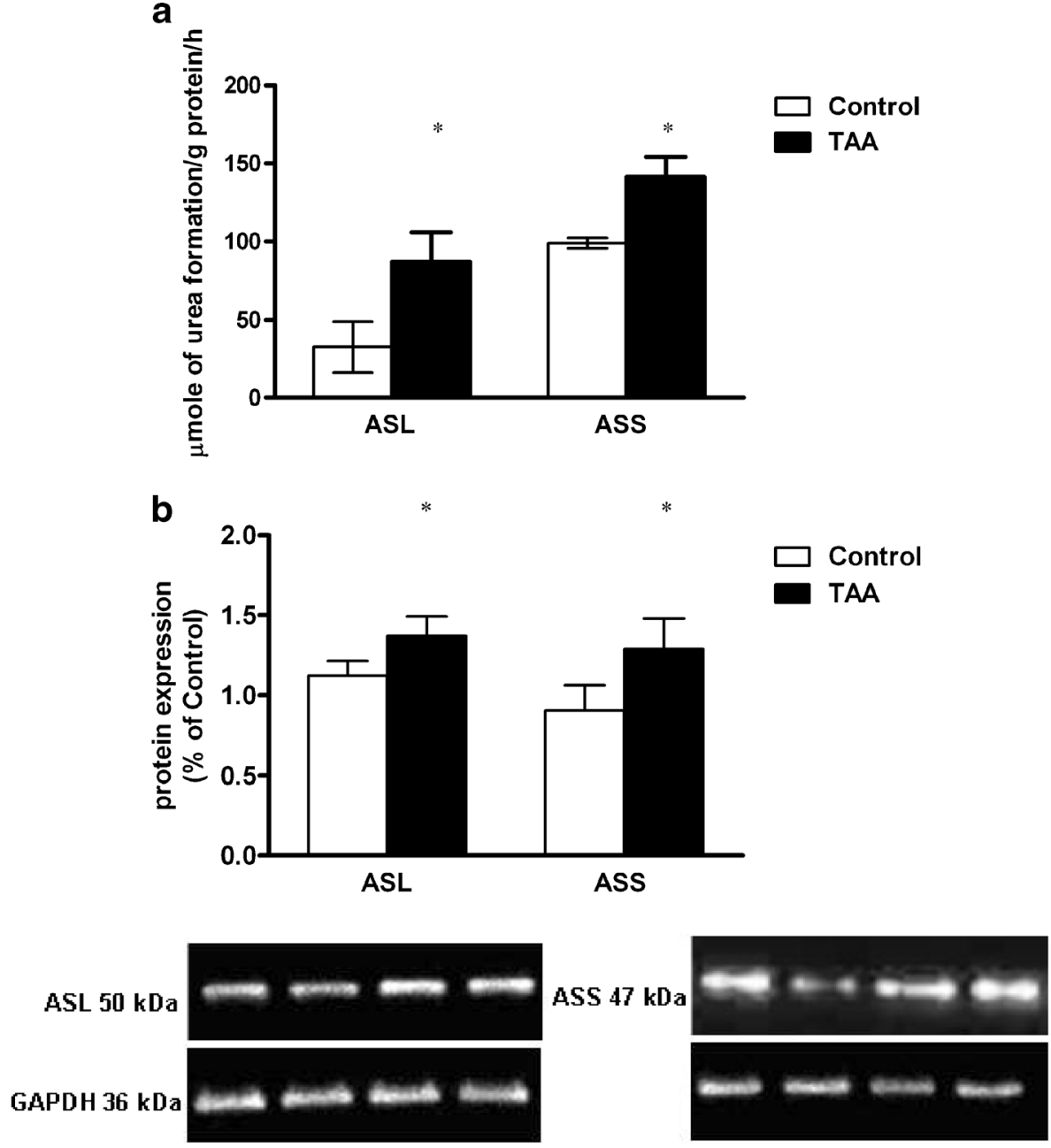
synthesis in vivo. Exact evaluation of the contribution of Cit transport that could be a regulatory mechanism capable of modulating NO synthesis in the different CNS cell types will require further investigation.

Acknowledgments The study was supported by Polish Ministry of Science and Education, grant no NN401037839.

Open Access This article is distributed under the terms of the Creative Commons Attribution License which permits any use, distribution, and reproduction in any medium, provided the original author(s) and the source are credited.

\section{References}

Albrecht J, Jones EA (1999) Hepatic encephalopathy: molecular mechanisms underlying the clinical syndrome. J Neurol Sci 170:138-146

Albrecht J, Norenberg MD (2006) Glutamine: A Trojan horse in ammonia neurotoxicity. Hepatology 44:788-794

Albrecht J, Hilgier W, Rafałowska U (1990) Activation of arginine metabolism to glutamate in rat brain synaptosomes in thioacetamide-induced hepatic encephalopathy: an adaptative response? J Neurosci Res 25:125-130

Albrecht J, Hilgier W, Januszewski S, Quack G (1996) Contrasting effects of thioacetamide-induced liver damage on the brain uptake indices of ornithine, arginine and lysine: modulation by treatment with ornithine aspartate. Metab Brain Dis 11:229-237

Balasubramaniyan V, Wright G, Sharma V, Davies NA, Sharifi Y, Habtesion A, Mookerjee RP, Jalan R (2012) Ammonia reduction with ornithine phenylacetate restores brain eNOS activity via the DDAH-ADMA pathway in bile duct-ligated cirrhotic rats. Am J. Physiol Gastrointest Liver Physiol 302:G145-152

Bradford MM (1976) A rapid and sensitive method for the quantitation of microgram quantities of protein utilizing the principle of protein-dye binding. Anal Biochem 72:248-254

Braissant O, Honegger P, Loup M, Iwase K, Takiguchi M, Bachmann C (1999) Hyperammonemia: regulation of argininosuccinate synthetase and argininosuccinate lyase genes in aggregating cell cultures of fetal rat brain. Neurosci Lett 266:89-92

Cooper AJ, Plum F (1987) Biochemistry and physiology of brain ammonia. Physiol Rev 67:440-519

Felipo V (2006) Contribution of altered signal transduction associated to glutamate receptors in brain to the neurological alterations of hepatic encephalopathy. World J Gastroenterol 12:7737-7743

Felipo V, Butterworth RF (2002) Neurobiology of ammonia. Prog Neurobiol 67:259-279

Fike CD, Sidoryk-Wegrzynowicz M, Aschner M, Summar M, Prince LS, Cunningham G, Kaplowitz M, Zhang Y, Aschner JL (2012) Prolonged hypoxia augments L-citrulline transport by system A in the newborn piglet pulmonary circulation. Cardiovasc Res 95:375-384

Fotiadis D, Kanai Y, Palacín M (2013) The SLC3 and SLC7 families of amino acid transporters. Molecular Aspects of Medicine 34:139-158

Garthwaite J, Charles SL, Chess Williams R (1988) Endothelium-derived relaxing factor release on activation of NMDA receptors suggests role as intercellular messenger in the brain. Nature 336:385-388

Hazell AS, Norenberg MD (1998) Ammonia and manganese increase arginine uptake in cultured astrocytes. Neurochem Res 23:869-873

Hermenegildo C, Montoliu C, Llansola M, Munoz MD, Gaztelu JM, Minana MD, Felipo V (1998) Chronic hyperammonemia impairs the glutamate-nitric oxide-cyclic GMP pathway in cerebellar neurons in culture and in the rat in vivo. Eur J Neurosci 10:3201-3209
Hermenegildo C, Monfort P, Felipo V (2000) Activation of N-methyl-Daspartate receptors in rat brain in vivo following acute ammonia intoxication: characterization by in vivo brain microdialysis. Hepatology 31 : 709-715

Hilgier W, Olson JE (1994) Brain ion and amino acid contents during edema development in hepatic encephalopathy. J Neurochem 62:197-204

Hilgier W, Puka M, Albrecht J (1992) Characteristics of large neutral amino acid-induced release of preloaded L-glutamine from rat cerebral capillaries in vitro: effects of ammonia, hepatic encephalopathy, and gamma-glutamyl transpeptidase inhibitors. J Neurosci Res 32: 221-226

Hilgier W, Olson JE, Albrecht J (1996) Relation of taurine transport and brain edema in rats with simple hyperammonemia or liver failure. $\mathrm{J}$ Neurosci Res 45:69-74

Hilgier W, Oja SS, Saransaari P, Albrecht J (2004) A novel glycine sitespecific N-methyl-D-aspartate receptor antagonist prevents activation of the NMDA/NO/CGMP pathway by ammonia. Brain Res 1015:186-188

Hilgier W, Fresko I, Klemenska E, Beresewicz A, Oja SS, Saransaari P, Albrecht J, Zielinska M (2009) Glutamine inhibits ammoniainduced accumulation of cGMP in rat striatum limiting arginine supply for NO synthesis. Neurobiol Dis 35:75-81

Ishihara T, Takada T, Shoji Y, Uedono Y, Takeyama N, Tanaka T (1998) Hyperammonemia reduces water immersion-restraint stress gastric ulcers in rats. Gen Pharmacol 1:87-91

Kosenko E, Llansola M, Montoliu C, Monfort P, Rodrigo R, Hernandez-Viadel M, Erceg S, Sánchez-Perez AM, Felipo V (2003) Glutamine synthetase activity and glutamine content in brain: modulation by NMDA receptors and nitric oxide. Neurochem Int 43:493-499

Leung TM, Lu Y, Yan W, Morón-Concepción JA, Ward SC, Ge X, Conde de la Rosa L, Nieto N (2012) Argininosuccinate synthase conditions the response to acute and chronic ethanol-induced liver injury in mice. Hepatology 55:1596-609

Livak KJ, Schmittgen TD (2001) Analysis of relative gene expression data using real-time quantitative PCR and the 2(-Delta Delta $\mathrm{C}(\mathrm{T})$ ) method. Methods 25:402-408

Martinez-Hernandez A, Bell KP, Norenberg MD (1977) Glutamine synthetase: glial localization in brain. Science 195:1356-1358

Nakakariya M, Shima Y, Shirasaka Y, Mitsuoka K, Nakanishi T, Tamai I (2009) Organic anion transporter OAT1 is involved in renal handling of citrulline. Am J Physiol Renal Physiol 297:F71-F79

Prakash R, Mullen KD (2010) Mechanisms, diagnosis and management of hepatic encephalopathy. Nat Rev Gastroenterol Hepatol 7:515-525

Rao VL (2002) Nitric oxide in hepatic encephalopathy and hyperammonemia. Neurochem Int 41:161-70

Rao VL, Butterworth RF (1996) L-[3H]Nitroarginine and L-[3H]arginine uptake into rat cerebellar synaptosomes: kinetics and pharmacology. J Neurochem 67:1275-1281

Rao VL, Audet RM, Butterworth RF (1997) Portacaval shunting and hyperammonemia stimulate the uptake of $\mathrm{L}-[3 \mathrm{H}]$ arginine but not of L- $[3 \mathrm{H}]$ nitroarginine into rat brain synaptosomes. J Neurochem 68 : 337-343

Rodrigo R, Erceg S, Rodriguez-Diaz J, Saez-Valero J, Piedrafita B, Suarez I, Felipo V (2007) Glutamate-induced activation of nitric oxide synthase is impaired in cerebral cortex in vivo in rats with chronic liver failure. J Neurochem 102:51-64

Schliess F, Görg B, Fischer R, Desjardins P, Bidmon HJ, Herrmann A, Butterworth RF, Zilles K, Häussinger D (2002) Ammonia induces MK-801-sensitive nitration and phosphorylation of protein tyrosine residues in rat astrocytes. FASEB J 16:739-741

Schmidlin A, Fischer S, Wiesinger H (2000) Transport of L-citrulline in neural cell cultures. Dev Neurosci 22:393-398

Sharma V, Ten Have GA, Ytrebo L, Sen S, Rose CF, Dalton RN, Turner C, Revhaug A, van-Eijk HM, Deutz NE, Jalan R, Mookerjee RP, 
Davies NA (2012) Nitric oxide and L-arginine metabolism in a devascularized porcine model of acute liver failure. Am J Physiol Gastrointest Liver Physiol 303:G435-441

Swamy M, Zakaria AZ, Govindasamy C, Sirajudeen KN, Nadiger HA (2005) Effects of acute ammonia toxicity on nitric oxide (NO), citrulline-NO cycle enzymes, arginase and related metabolites in different regions of rat brain. Neurosci Res 53:116-122

Vadgama JV, Evered DF (1992) Characteristics of L-citrulline transport across rat small intestine in vitro. Pediatr Res 32:472-478

Westergaard N, Beart PM, Schousboe A (1993) Transport of L$[3 \mathrm{H}]$ arginine in cultured neurons: characteristics and inhibition by nitric oxide synthase inhibitors. J Neurochem 61: 364-367

Wileman SM, Mann GE, Pearson JD, Baydoun AR (2003) Role of Lcitrulline transport in nitric oxide synthesis in rat aortic smooth muscle cells activated with LPS and interferon-g. Br J Pharmacol 140:179-185
Wu G, Meininger CJ (1993) Regulation of L-arginine synthesis from Lcitrulline by L-glutamine in endothelial cells. Am J Physiol 265: H1965-H1971

Zhang WY, Takiguchi M, Koshiyama Y, Gotoh T, Nagasaki A, Iwase K, Yamamoto K, Takshima H, Negi A, Mori M (1999) Expression of citrulline-nitric oxide cycle in lipopolysaccharide and cytokinestimulated rat astroglioma C6 cells. Brain Res 849:78-84

Zielińska M, Hilgier W, Law RO, Goryński P, Albrecht J (1999) Effects of ammonia in vitro on endogenous taurine efflux and cell volume in rat cerebrocortical minislices: influence of inhibitors of volume-sensitive amino acid transport. Neuroscience 91: $631-638$

Zielinska M, Ruszkiewicz J, Hilgier W, Fresko I, Albrecht J (2011) Hyperammonemia increases the expression and activity of the glutamine/arginine transporter y+LAT2 in rat cerebral cortex: implications for the nitric oxide/cGMP pathway. Neurochem Int 58:190-195 